\title{
Audit Committee and Classification Shifting of Earnings Management: Evidence from Sub-Sahara African Firms
}

\author{
ORJINTA, HOPE IFEOMA \\ DEPARTMENT OF ACCOUNTANCY \\ FACULTY OF MANAGEMENT SCIENCES, \\ CHUKWUEMEK A ODUMEGWU OJUKWU UNIVERSITY \\ IGBARIAM CAMPUS, ANAMBRA STATE, NIGERIA \\ Email: Ifyorjinta@gmail.com \\ Phone Number: +2348060127990 \\ VEN. DR. ONUORA, JKJ \\ DEPARTMENT OF ACCOUNTANCY \\ FACULTY OF MANAGEMENT SCIENCES, \\ CHUKWUEMEK A ODUMEGWU OJUKWU UNIVERSITY \\ IGBARIAM CAMPUS, ANAMBRA STATE \\ Phone Number: +2348035810553
}

Dr. (MRS) AGUBATA, NONYE, S.

DEPARTMENT OF ACCOUNTANCY

FACULTY OF MANAGEMENT SCIENCES,

CHUKWUEMEK A ODUMEGWU OJUKWU UNIVERSITY

IGBARIAM CAMPUS, ANAMBRA STATE, NIGERIA

Phone Number: +2348036685030

DOI: 10.31364/SCIRJ/v6.i10.2018.P1018576

http://dx.doi.org/10.31364/SCIRJ/v6.i10.2018.P1018576

\begin{abstract}
This study investigated whether managers use classification shifting to reclassify recurring expenses into non-recurring ones, placing more emphasis on the effect of audit committee in curbing such opaque manipulations. A sample of 75 quoted non-financial firms from three Sub-Sahara African countries (Nigeria, Kenya and South Africa) was used for the period of ten years spanning 2008 to 2017 . The study employed ex-post facto and cross-sectional research design in analyzing secondary data collected. Using a methodology similar to McVay (2006) and a sample of 750 Sub-Sahara African firm-year observations, our result revealed that classification shifting is less prevalent in firms whose audit committee is characterized by more meetings, more financial expert members and more independent directors as this leads to lower levels of recurring items misclassification. Specifically, our result discovered that audit committee independence has negative and significant effect on classification shifting which was statistically significant at $10 \%$ level of significance while audit financial expertise and audit committee diligence have negative and significant effect on classification shifting at $1 \%$ and $5 \%$ levels of significance respectively. The findings showed that about $\mathbf{6 8 . 4 \%}$ of changes in total variation in the classification shifting of earnings management can be attributed to the joint effect of all the explanatory variables while about $31.6 \%$ was unaccounted for thereby captured by stochastic error term. However, based on the following findings, we suggest that users of financial statements should take account of firms' audit committee composition when evaluating firms' core earnings.
\end{abstract}

Keywords: Earnings management, classification shifting, non-recurring items, audit committee

\subsection{INTRODUCTION}

Accounting is seen as the language of business since it provides the firm's external users with financial information. Using this, stakeholders can analyze the firm's operating and financial performances to help them in decision making process. This information can be found in companies' financial reports that are prepared by managers based on accounting standards. Due to number of accounting scandals at companies such as Enron and WorldCom which resulted in the decreased investor confidence in the quality of corporate financial information. For instance, Enron deliberately shifted its liabilities and losses as part of core expenses to non- 
consolidated special purpose entities (Lobo and Zhou, 2006). This misclassification led to an unexpected non-recurring charge of $\$ 1.01$ billion in October 2001 and a corresponding increase in core earnings. Even though that Wu (2016) opined that accounting rules allow managers with great discretion on the choices of classification shifting that affect the presentation and disclosure of items on the financial statements, managers are further incentivized to indulge in earnings manipulation due to their compensation being tied to the firms"e performance. Cameron and Gallery (2012) argue that managers can achieve higher "normal earnings" by classifying normal expenses as unusual, special, significant, exceptional, abnormal, or extraordinary items. These items are transitory, not persistent and not expected to recur. Classification shifting of income statement items is used as an earnings management tool to shift items with a recurring nature to items with a non-recurring nature in order to increase core earnings while net earnings remain equal. Misclassified income statement components indicate that the financial statements do not provide a true and fair view of the financial statement, which is a violation of an objective of the conceptual framework. It is expected that classification shifting is used in Nigerian firms to overstate core earnings because non-recurring items are lightly regulated according to the International Financial Reporting Standard (IFRS). The proper classification of expenses within the income statement is subject to management discretion and less explicit disclosures requirement and definition (Athanasakou, Strong and Walker 2009; McVay, 2006). Prior research indicates that classification shifting does not affect the net income of a company, but significantly affects perceptions of persistence and growth associated with a company. The distinction is important, because unlike accrual-based earnings management, classification shifting is a disclosure issue that does not process through accounting systems and does not affect bottom line earnings and thus is more difficult to verify (Athanasakou, Strong, \& Walker, 2009) offering a powerful setting to test the effects of audit committee quality on earnings quality (Frankel, McVay, \& Soliman, 2011). According to this viewpoint, using effective audit committee characteristics to improve the internal and external control of managers (for example, by monitoring the board of directors) may decrease opportunities for earnings management and improve the credibility of financial information (Dey 2005; Rogers 2006). From a rational standpoint, earnings management is a consequence of the agency problem and it can be mitigated by a good audit committee structure. In other words, good audit committee components can be considered a means of controlling managers in the realm of monitoring and corporate reporting.

Accounting research has focused extensively on both discretionary accrual-based earnings management (DA) and real earnings management (REM). The third route of earnings management which is Classification Shifting (CS) is a relatively new research area. Only a few studies like McVay (2006); Fan, Barua, Cready and Thomas (2010) and Barua, Lin and Sbaraglia (2010) have recently focused on another form of earnings management through classification shifting (CS).This Classification shifting has received less attention than either accrual-based or real earnings management. Moreover, the classification shifting approach to earnings management has been found in developed country and scholars did not do many researches in this field and the understanding is still limited. The relatively few studies on classification shifting primarily focused on motivations and provided compelling evidence that management are motivated to misclassify recurring expenses as non-recurring when such practices allows them to meet or beat predetermined earnings benchmarks (Athanasakou et al., 2009; Barua, Lin and Sbaraglia, 2010; Fan, Barua, Cready \& Thomas, 2010; McVay, 2006).

Again, there are inconsistencies in the findings of prior studies. For example Xie, Davidson and DaDalt (2003) found that accrualbased earnings management is positively related to board tenure, Klein, (2002); Peasnell Pope and Young (2005) observed that accrual-based earnings management is positively related to the proportion of independent directors while Hossain, Mitra, Rezaee and Sarath (2011); Xie et al., (2003) have found number of meetings to be negatively associated with accrual-based earnings management. Similarly, audit committee size documented by Yang and Krishnan (2005), number of meetings found by Xie et al., (2003), members' outside directorships observed by Bedard, Chtourou and Courteau (2004) and Yang and Krishnan (2005), financial expertise also noted by Bedard et al., (2004); Hossain, Mitra, Rezaee and Sarath (2011); Xie et al., (2003), and tenure documented by Yang and Krishnan (2005) reduce accruals management, while Bedard et al. (2004) and Yang and Krishnan (2005) found that stock ownership by audit committee members is positively related to accruals management

It is therefore evident from the above studies that the extant literature has created more need for further studies to substantiate the direction of the relationship between corporate board and classification shifting. All this prior literature ignored classification shifting as a means of managing earnings. We instead argued that the ability to deliberately misclassify operating expenses is not the same across all firms and that audit committee may mitigate classification shifting. Hence it may be concluded that the relationship between audit committee and earnings management using classification shifting must be investigated to better generalize the results for future propositions in this regard. Furthermore, to the best of our knowledge, there is no known research conducted in Sub-Sahara Africa on the effect of audit committee on earnings management using classification shifting.

WWW.scirj.org

(C) 2018, Scientific Research Journal

http://dx.doi.org/10.31364/SCIRJ/v6.i10.2018.P1018576 
Therefore, this study aims to investigate the effect of audit committee on earnings management using classification shifting approach among quoted non-financial firms in Sub-Sahara African countries.

Against this backdrop, the following objectives were raised to guide this study.

I. Evaluate the effect of Audit Committee Independence on classification shifting of earnings management of quoted nonfinancial firms in Sub-Sahara African countries.

II. Ascertain the effect of audit committee financial expertise on classification shifting of earnings management of quoted nonfinancial firms in Sub-Sahara African countries.

III. Examine the extent to which audit committee diligence influence classification shifting of earnings management of quoted non-financial firms in Sub-Sahara African countries.

\subsection{THEORETICAL CONSTRUCTS}

\subsubsection{Classification shifting}

Classification shifting (CS) can be explained as an earnings management strategy whereby managers move items within the income statement to improve core earnings (McVay; 2006). It is distinct from other two earnings management methods (real earnings management and accruals earnings management). Classification Shifting involves managers' deliberate misclassification of core expenses as non-recurring or special items on the statement of comprehensive income to create the illusion of an increase in core earnings for investors (Haw, Ho \& Li 2011). CS is not related to the recognition or the measurement of items; rather, it is related to the misclassification of recurring expenses (operating expenses) as non-recurring expenses within the income statement to inflate the core earnings number instead of bottom line net income of firms. This can be achieved by shifting expenses downwards from recurring items to non-recurring.

Figure 1. MECHANISM OF CLASSIFICATION SHIFTING (CS)

\begin{tabular}{|c|c|c|c|c|}
\hline Income Statement & \# 'millions' & Income Statement & \# 'millions' & \\
\hline Sales & 400 & Sales & 400 & \\
\hline Core Expenses & $(350)$ & Core Expenses & (330) & \\
\hline Core Earnings & 50 & Core Earnings & 70 & shifting \\
\hline Non-recurring items & 10 & Non- recurring items & 30 & \\
\hline Net Income & 40 & Net Income & 40 & \\
\hline
\end{tabular}

Source: Researcher's Conception (2018)

Figure 1 above illustrates how reclassification of core expenses items (operating expenses) to non-recurring items intentionally increased core earnings (operating income) from 50 million to 70 million. By shifting core expenses to non-recurring/special items, managers of firms increases core earnings while bottom-line net income remains unaffected. This is to show you that management (corporate board) has an incentive to use classification shifting for earnings adjustment in a way that does not damage firm value to either boost their profit or avoid reporting losses. Classification shifting may be preferred to other earnings management methods both because it does not change GAAP net income so potentially reducing the scrutiny of auditors and regulators, and because it does not affect future earnings as there are no accruals which reverse in the next period or loss of future revenue from forgone opportunities (Athanasakou et al., 2009; McVay, 2006).

To document classification shifting, we focused on the allocation of expenses between core expenses (defined as cost of goods sold and selling, general, and administrative expenses) and non-recurring (special items). We posit that managers wishing to manage core earnings upward will shift expenses that should be classified as core expenses to special items. Classification shifting does not change reported results but the structure of income statement, so we can find the changes from core earnings not reporting results. In the words of Zalata and Roberts (2016), they opined that Classification shifting is not related to the recognition or the measurement of items; rather, it is related to the misclassification of recurring expenses as non-recurring within the income statement. In particular, classification shifting can be achieved by shifting expenses down from recurring items to non-recurring and exceptional items, and therefore inflate their core earnings number instead of bottom line net income. For example, a recurring expense related to maintenance of manufacturing facilities could be treated as a one-time special item and be treated as non-recurring expense to inflate core earnings. Such misclassification of expenses does not affect the bottom line of the company; it only misrepresents the core earnings of a company. The main aim of classification shifting is generally to inflate firms' core earnings through the misclassification of some recurring expenses or operating expenses as non-recurring within the income statement. Unlike recurring www.scirj.org

(C) 2018, Scientific Research Journal

http://dx.doi.org/10.31364/SCIRJ/v6.i10.2018.P1018576 
expenses, non-recurring expenses are by definition infrequent or transitory and financial statement users, especially less sophisticated investors, appear not to understand their nature and weight individual categories within the income statement differentially (e.g., Bhattacharya, Black, Christensen \& Mergenthaler 2007; Bradshaw \& Sloan, 2002). This might motivate some managers to misclassify a portion of their recurring expenses as non-recurring thereby inflating their core earnings. CS may be preferred to other earnings management methods both because it does not change GAAP net income so potentially reducing the scrutiny of auditors and regulators, and because it does not affect future earnings as there are no accruals which reverse in the next period or loss of future revenue from forgone opportunities (Athanasakou et al., 2009; McVay, 2006).

\subsubsection{Audit Committee Independence}

Corporate board norms in most developed and developing countries like Nigeria require the constitution of a board audit committee that is free from management interference and bias to oversee the financial reporting and auditing process. Professional accounting and auditing bodies endorse the constitution of audit committee independence as it lends greater credibility to financial statements and enhances public confidence in the integrity of the external auditor. The main important qualities of the right people are independence and competencies. The requirement is that audit committee members should be composed of at least three independent directors to enable the audit committee members make judgments that are in the best interests of shareholders and to promote objectivity on the part of audit committee members (DeZoort et al., 2002 as cited by Sri and Sylvia, 2016). Audit committee members must not have any relationship with the company so that it will not interfere with the exercise of their independence. Afify (2009) noted that larger proportion of independent directors on the board makes the committee more effective in monitoring management behaviour and this in return reduces the nature of inherent risk. The importance of outside directors has been recognized even at the level of policy, with codes of corporate governance giving a special attention to the need to have a reasonable proportion of them on the board of listed firms. Emeh and Appah (2013) observed that audit committee should be independent from management in order to be able to conduct effective monitoring, resulting in less opportunistic management behavior such as misclassification of items in the reporting architecture. Sri and Sylvia (2016) maintained that audit committees with independent members appear to be more active, more involved in audit committee functions and less likely to be involved in actions that impinge on the quality of financial reporting.

\subsubsection{Audit Committee Financial Expertise}

Audit committee expertise is referred to as the audit committee members who have the knowledge and experiences in accounting and financial reporting, internal controls and auditing. Prior studies refer to audit committee financial expertise as the audit committee members who have membership in any accounting body or association (Hashim and Rahaman, 2011; Mohamad Shafie and Wan 2010). Since audit committees have numerous duties and responsibilities, they require a high degree of accounting sophistication such as understanding auditing issues and risks (Habbash, 2010). The experience and knowledge in accounting and auditing related issues is considered as an important dimension for an audit committee, this advantage can help the audit committee members to be more conversant with financial and operational reports that enable them to execute their oversight duties effectively. It is the responsibility of the board to ensure that the committee is constituted in the manner stipulated and is able to effectively discharge its statutory duties and responsibilities. At least one board member of the committee should be financially literate; members of the committee should have basic literacy and should be able to read financial statements. At least one member should have knowledge of accounting or financial management, whenever necessary; the committee may obtain external professional advice.

\subsubsection{Audit Committee Diligence.}

Audit committee diligence is evidenced by the number of committee meetings. DeZoort (2002) argued that the number of committee meetings have effect on audit committee effectiveness. Habbash (2010) argued that the establishment of an audit committee is meant to ensure continuous communication between external auditors, internal auditors and the board where the committee meets regularly with the auditors to review the financial statements and audit processes as well as the internal accounting systems and controls. The frequency of meeting held shows continuous engagement within the members of the committee to discuss any related issues for continuous improvement (Abbott, Parker and Peter: 2004). Sharinah, Salleh and Azlinah (2014) argued that small number of meetings or no meeting at all held in a year by the audit committee indicate bad monitoring practices. Nigerian Code of Corporate Governance required that audit committee of a listed company shall meet at least once every quarter of the financial year. These meetings shall be held prior to the approval of interim results of the listed company by its Board of Directors and before and after completion of external audit. A meeting of the Audit Committee shall also be held, if requested by the external auditors or the head of internal audit. Previous research has shown that a number of audit committee meeting can reduce earning management behavior of the executive (Klien; 2002, Sharma Naiker and Lee; 2009 \& Lin and Hwang; 2010).

\section{2: $\quad$ THEORETICAL FRAMEWORK \\ 2.2.1: $\quad$ Positive Accounting theory}

WWW.scirj.org 
Besides Agency Theory, the Positive Accounting Theory (PAT) has been one of the most important accounting theories in the last decades. Watts and Zimmerman (1986) developed the positive accounting theory that aims to explain and predict accounting practice. It is concerned with actions such as which accounting policies management chooses and how management responds to proposed new accounting standards. It explains earnings management in the preparation of reported financial statements. That is why this article is anchored on positive accounting theory. In accounting research two literature streams are identified: normative and positive theory. Normative theories are concerned with an attempt to tell individuals what they should do while positive theory describes, explains and predicts particular behavior. What drives managers' decisions to choose certain accounting policies? According to Scott (2012) PAT is concerned with predicting such actions as the choices of accounting policies by firm managers and how managers will respond to proposed new accounting standards. Moreover, the aim of this theory is to understand and predict the choice of accounting policies across different firms, recognizing that economic consequences exist. Economic consequences refer to the impact of accounting reports on the decision making behavior of business, government and creditors. This implies that accounting information can affect real decisions made by managers and other stakeholders rather than only reflecting the results of these decisions. Watts and Zimmerman's (1986) Positive Accounting Theory posits that accounting numbers facilitate the contracting process and thus reduce agency costs.

Accounting regulation provides an existing framework for the calculation of accounting measures and adapting these rules avoids substantial costs of designing individual contracts with numerous performance measures and contingencies (Lambert, 2003), and the auditing process and the public availability of accounting data makes accounting measures more reliable and transparent than some complicated performance measure "home-cooked" by the local controlling department. Prominent examples for accounting-based contracts are management compensation plans and debt contracts (Watts \& Zimmerman, 1986). Management compensation plans are often linked to accounting related performance indicators and accounting is required for the calculation of management payouts. Debt covenants are based on financial ratios (such as interest coverage) derived from accounting figures and accounting data is required to monitor whether covenants were breached. In both cases, the allocation of the firm's cash flows among participating parties depends on the accounting process. Consequently, such contracts motivate self-interested individuals to exercise (opportunistic) accounting discretion (i.e., earnings management).

\section{3: $\quad$ EMPIRICAL LITERATURE AND HYPOTHESES DEVELOPMENT}

\subsection{1: Audit Committee Independence and Earnings Management (Classification Shifting)}

The influence of various characteristics of audit committees including the committee's existence, the independence of the committee directors, the presence of executive directors and individuals with financial expertise on the committee and the committee's meeting frequency and size, have been the subject of numerous prior studies. Klein (2002) demonstrated a significant negative relationship between an independent member majority in audit committees and abnormal accruals. Klein (2002) further revealed that higher proportion of outside directors on the audit committee (i.e. audit committee independence) is associated with lower earnings management, suggesting that audit committee independence reflects governance quality. Benkel, Mather and Ramsay (2006) asserted that a higher portion of independent directors on audit committees yields diminutive levels of earnings management. Davidson, Goodwin-Stewart and Kent (2005) provided evidence of a negative association between the existence of an audit committee and a majority of non- executive director committee members on reducing earnings management. Choi Jeon and Park (2004) and Park and Shin (2003) found a significant relationship between the audit committee and earning management. In contrast, Peasnell et al. (2005) and Rahman and Ali (2007) found no significant relationship. Peter and Cotter (2009) examined the relation between audit committees and (improved) earnings quality using a sample of Australian listed firms. The relation investigated is prior to the introduction of the binding audit committee requirements in 2003. Earnings quality was measured by the Jones model and the Dechow and Dichev (2002) model. Their results show that the existence of an audit committee does not decrease accrual estimation errors but reduces intentional earnings management. However, there are some inconsistencies that existed in the literature, for that reason, the current study does not intend to propose any sign, rather we hypothesize that there is a significant relation between audit committee independence and classification shifting (Hypothesis 1).

\subsubsection{Audit Committee Financial Expertise and Earnings Management (Classification Shifting)}

A number of studies have documented a negative association between the financial and accounting expertise in the audit committee and earnings management. Similarly, Xie et al., (2003) found that audit committee members with accounting and financial knowledge are associated with companies that have smaller discretionary current accruals as proxy for earnings management. Studies of DeZoort and Salterio (2001) and Bédard et al; (2004) found that audit committee members with accounting and financial expertise provide 
more support on auditing output and to reduce problems on auditor's disagreement, as well as to confine earnings management. Prior studies demonstrate that audit expertise can control fraud and earnings restatements, which are measures that affect earnings management (Abbott, Parker, and Peters, 2003; Agrawal and Chadha, 2005). Carcello, Hollingsworth, Klein and Neal (2006) indicate a high correlation between the composition of the audit committee and earnings management. Carcello et al. (2006) further documented a trade-off between financial expertise and other corporate governance mechanisms. Although audit committee financial expertise cannot provide an incremental effect on the reduction of earnings management, it can have an influential effect on firms with other poor corporate governance mechanisms. Further, for firms with other weak corporate governance mechanisms, both accounting and financial expertise can mitigate earnings management. They also found that the most effective composition of the audit committee to control opportunistic earnings management includes independent audit directors with accounting or financial expertise. In addition, Felo, Krishnamurthy and Solieri (2003) found a positive relation between the number of audit committee members with financial expertise and financial reporting quality implicating that when the number of members with financial expertise increases, the quality of the financial statements also increases. Also some researchers investigated which type of expertise (finance, accounting, or supervisory) improved the quality of accruals most (Dhaliwal et al., 2010). Another US study finds that audit committees with financial expertise can reduce earnings management (Bedard et al., 2004). Prior studies also demonstrate that audit committee independence can reduce opportunistic earnings manipulation (Turner \& Vann, 2010). Nigerian code of corporate governance imposes the requirement that an audit committee must include at least one financial expert. This study proposes that the audit committee with accounting expertise would lead to less earnings management practice. Therefore we hypothesize that there is $\boldsymbol{a}$ significant negative relation between audit committee financial expertise and classification shifting (Hypothesis 2).

\subsection{3: Audit Committee Diligence and Earnings Management (Classification Shifting)}

Based on prior studies of Xie, Davidson and Dadalt (2003) and Mohamad, Shafie and Wan. (2010), audit committee diligence is expressed by the number of meetings held in a year. Wasukan (2015) opined that the number of meeting can also continuously provide knowledge and information to audit committee, especially in accounting, auditing and other knowledge whereas inappropriate meeting number is indicative of the lack of effective corporate governance. The result of Li, Pike and Haniffa (2008) showed that frequent audit committee meeting is positively related with level of corporate disclosure while that of Xie, Davidson and Dadalt (2003) showed that when audit committee meets more frequently that discretionary accruals are lower. Again, Abbot et al (2004) and Persons (2009) asserted that the higher level of audit committee meeting is significantly related to a lower incidence of financial restatement or reporting a small earnings increase, or fraudulent financial reporting. Mohamad, Shafie and Wan (2010) documented that firms with more members in the audit committee and more number of audit committee meetings, are more likely to produce audit reports in timely manner. In addition, Abbott et al. (2004) noted that, with frequent meetings, audit committee will remain informed and knowledgeable about accounting or auditing issues and can direct internal and external audit resources to address the matter. Sharinah, Salleh and Azlinah (2014) reported that small number of meetings or no meeting at all held in a year by the audit committee indicate bad monitoring practices. This assertion was supported by Xie et al. (2003) who found that audit committee activity influences the monitoring effectiveness while Mohamad-Nor et al. (2010) found that audit committee meeting is negatively associated with earnings management. The study of Wasukan (2015) showed that number of board meeting has a positive correlation with earning management, which is consistent with the concept of Jensen (1993) as Jensen stated that management of a company that holds board meeting too often will lose too much time in the meeting instead of overseeing management performance. A review of relevant empirical studies showed that most studies on audit committee diligence and financial reporting quality do not find significant relationships. Previous research has shown that a number of audit committee meeting can reduce earnings management behavior of the executive (Klien; 2002, Sharma Naiker and Lee; 2009, Lin and Hwang; 2010).Therefore, they concluded that numbers of the meeting cannot reduce earnings management. However, given the conflicting theoretical arguments, this current study does not intend to predict any sign for audit committee diligence: All things being equal, there is a significant relationship between audit committee diligence and classification shifting (Hypothesis 3).

\section{0}

METHODOLOGY

The research design adopted in this study was ex-post facto research design and cross sectional data as 75 quoted companies that cut across all the non-financial firms in Sub-Sahara Africa (Kenya, Nigeria and South Africa) was covered and used to describe whether audit committee collaborates or substitute classification shifting. The study utilized secondary data as the main source of information which covered selected quoted non-financial firms within the period of ten years spanning 2008 to 2017. The information relating to the features of audit committee (audit committee independence, audit committee financial expertise and audit committee meeting) were used as independent variables and earnings management measured with classification shifting was used as our dependent variable while return on assets and firm size were used as control variables. All the variables were analyzed using ordinary least square regression.

To examine whether crucial audit committee attributes mitigates classification shifting, we concentrated on the misclassification of recurring expenses and investigated the association between unexpected core earnings and non-recurring expenses, and anticipate that

Www.scirj.org

(C) 2018, Scientific Research Journal

http://dx.doi.org/10.31364/SCIRJ/v6.i10.2018.P1018576 
firms' core earnings will be overstated in the period when non-recurring items are recognized. Following McVay (2006), we determined a proxy for normal core earnings for each of the 75 firms in the sample using the following expectation model as our step 1 :

EXP-CE $_{\mathrm{i}, \mathrm{t}}=\beta_{0}+\beta_{1} \mathrm{CE}_{\mathrm{t}-1}+\beta_{2} \mathrm{ATO}_{\mathrm{i}} \mathrm{t}+\beta_{3} \mathrm{ACCRUALS}_{\mathrm{t}-1}+\beta_{4} \mathrm{ACCRUALS}_{\mathrm{t}}+\beta_{5} \mathrm{SALES}_{\mathrm{i}, \mathrm{t}}+\beta_{6} \mathrm{NEG}_{-} \quad{ }_{\Lambda}$ SALES $+\varepsilon_{\mathrm{It}}$

The following table below shows how variables in Step 1 above were measured:

\section{Variables}

$\mathbf{C E}$

\section{Asset Turnover (ATO)}

\section{ACCRUALS \\ ASALES}

NEG. ASALES

\section{Source: Researchers computation (2018)}

We included lagged core earnings $\left(\mathrm{CE}_{\mathrm{t}-1}\right)$ in the model due to the fact that core earnings tend to be persistent. Asset turnover (ATO) was also included in the model to control for the indirect relationship between asset turnover and profit margin. This is crucial more especially for firms with large income increasing non-recurring items because these firms are more likely to have made changes to their operating strategies. As future performance is related to past accruals, lagged accruals $\left(\right.$ ACCRUALS $\left._{\mathrm{t}-1}\right)$ which are prior year operating accruals were added to capture the information content of last period accruals for current period earnings. Current period accruals $\left(\right.$ ACCRUALS $_{\mathrm{t}}$ ) were added to control for extreme performance arising from accruals management, therefore allowing for a strong prediction of abnormal excess of core earnings associated with classification shifting only. Sales growth $\left(\Lambda \mathrm{SALES}_{\mathrm{i}, \mathrm{t}}\right)$ was included to control for the impact of sales growth on fixed costs (as sales grow, fixed cost per unit decline) while negative sales

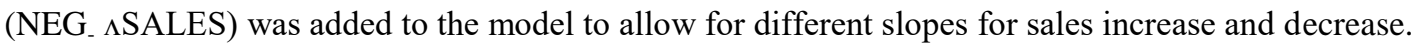

We then estimate the following model as our step 2 equation to investigate whether Sub-Sahara Africa firms misclassify recurring expenses into non-recurring items. Thus, the equation was captured as follows:

$$
\text { UNEXP-CE }=\beta_{0}+\beta_{1} N R E C_{1 t}+\text { Control variables }{ }_{1 t}+\varepsilon_{1 t . .}
$$

Where

UNEXP-CE means Unexpected Core Earnings computed as difference between reported core earnings and expected core earnings where the expected core earning value is calculated using the coefficients from Step (1) above while NREC stands for non-recurring items measured as the difference between reported core earnings and bottom line net income scaled by sales. When firms engage in classification shifting, the unexpected core earnings increases with non-recurring items and thus we expect coefficient of NREC $\left(\boldsymbol{\beta}_{1}\right)$ to be positive. A positive relationship between unexpected core earnings and non-recurring item is an evidence of classification shifting (CS). That is to say that the basic aim of classification shifting is to inflate firm's core earnings through the misclassification of some recurring expenses as non-recurring ones within the income statement. This also suggests that firms shift recurring/core expenses to non-recurring items to inflate core earnings, thus evidence of classification shifting (CS).

\section{Table 3.1: $\quad$ Regression of Unexpected Core Earnings on Non-Recurring Items}

UNEXP-CE $=\beta_{0}+\beta_{1} N R E C_{1 t}+$ Control

variables $_{1 t}+\mathcal{E}_{1 t}$

Dependent Variable: UNEXPCE 


\begin{tabular}{|c|c|c|c|c|}
\hline \multicolumn{5}{|c|}{$\begin{array}{l}\text { Method: Panel Least Squares } \\
\text { Date: 09/10/18 Time: } 11: 15 \\
\text { Sample: } 2008 \text { 2017 } \\
\text { Periods included: } 10 \\
\text { Cross-sections included: } 75 \\
\text { Total panel (balanced) observations: } 750\end{array}$} \\
\hline Variable & Coefficient & Std. Error & t-Statistic & Prob. \\
\hline $\mathbf{C}$ & 0.845941 & 0.250283 & 3.379943 & 0.0008 \\
\hline NREC & 30.78411 & 1.296397 & 23.74590 & 0.0000 \\
\hline FSIZE & -0.181316 & 0.004314 & -42.02699 & 0.0000 \\
\hline ROA & 5.708417 & 0.203722 & 28.02060 & 0.0000 \\
\hline R-squared & 0.773618 & \multirow{7}{*}{\multicolumn{2}{|c|}{$\begin{array}{l}\text { Mean dependent var } \\
\text { S.D. dependent var } \\
\text { Akaike info criterion } \\
\text { Schwarz criterion } \\
\text { Hannan-Quinn criter. } \\
\text { Durbin-Watson stat }\end{array}$}} & -6.935587 \\
\hline Adjusted R-squared & 0.772708 & & & 5.781251 \\
\hline S.E. of regression & 2.756220 & & & 4.870917 \\
\hline Sum squared resid & 5667.175 & & & 4.895557 \\
\hline Log likelihood & -1822.594 & & & 4.880411 \\
\hline F-statistic & 849.7735 & & & 1.133637 \\
\hline $\operatorname{Prob}(F-$-statistic) & 0.000000 & & & \\
\hline
\end{tabular}

\section{Source: Researchers' summary of regression result from Eview 8.0}

Before investigating whether corporate board mitigates classification shifting, we first of all investigated whether Sub-Sahara African non-financial firms currently see classification shifting as a viable manipulation method. Table 4.4 above shows basic regression testing conducted to investigate whether there is a positive relationship between non-recurring items (NREC) and unexpected core earnings (UNEXPCE), hence a positive coefficient value is assumed. As expected, it shows that, there is a significant positive relationship between NREC and UNEXPCE among our sampled firms. This suggests that some Sub-Sahara African firms might have shifted some recurring (core) expenses to non-recurring expenses to inflate their core earnings (core profit) which were an evidence of classification shifting. That is to show that classification shifting has become more pervasive in non-financial firms across Sub-Sahara African countries.

The result above shows that non-recurring expenses have positive effect on unexpected core earnings. The probability value shows that the effect of non recurring expenses on unexpected core earnings is statistically significant at $1 \%$ level. This means that as non recurring expenses is increasing, unexpected core earnings is also increasing, thus evidence of misclassification among firms quoted in Sub-Sahara Africa. The $\mathrm{R}^{2}$ indicates that non recurring expenses/items and other control variables can explain about $77 \%$ of changes in the unexpected core earnings. Thus, about $77 \%$ of changes in unexpected core earnings can be attributable to non recurring expenses while about $23 \%$ were unaccounted for.

Now that we have confirmed the existence and evidence of classification shift among selected non-financial firms in Sub-Sahara Africa, we can now proceed with the main regression analysis to see if audit committee collaborates or mitigate classification shifting, hence the analysis of unexpected core earnings with corporate board variables.

To test hypothesis 1 to 3, we included non-recurring items to further establish the evidence of classification shifting while return on asset (ROA) and firm size (FSIZE) were added as control variables to control for performance. The regression model then takes the following form:

\section{$U N E X P-C E=\beta_{0}+\beta_{1} N R E C_{1 t}+\beta_{2} A C I N D_{1 t}+\beta_{3} A C F X P_{1 t}+\beta_{4} A C D_{1 t}+\beta_{5} R O A_{1 t}+\beta_{6} A C D_{1 t}+\varepsilon_{1 t \ldots \ldots . . .(3)}$}

Where

UNEXP_CE $=$ Unexpected core earnings measured as difference between reported core earnings and expected core earnings. NREC stands for non-recurring items measured as the difference between reported core earnings and bottom line net income scaled by sales. ACIND means audit committee independence computed as the proportion of non-directors in the audit committee divided by the total number of audit committee members. ACFXP represents audit committee financial expertise captured as the proportion of financially literate audit committee members to the total number of audit committee members; ACD stands for audit committee diligence expressed in the number of meetings held by the audit committee members in a year; ROA is the return on assets measured as net income divided by the average total assets and FSIZE means firm size measured as the natural log of total assets. 
Table 4.1 below reports the descriptive statistics pertaining to the entirety of variables investigated in this study.

\begin{tabular}{|c|c|c|c|c|c|c|c|}
\hline Table 4.1: & Descriptive Sta & & & & & & \\
\hline & UNEXPCE & NREC & ACIND & ACFXP & ACD & ROA & FSIZE \\
\hline Mean & 1.4159 & 0.9285 & 0.4291 & 0.3644 & 10.005 & 0.5642 & 47.716 \\
\hline Median & 0.8900 & 0.0750 & 0.5000 & 0.3300 & 10.000 & 0.6100 & 46.700 \\
\hline Maximum & 340.55 & 226.97 & 0.7500 & 0.6500 & 14.000 & 1.5800 & 317.19 \\
\hline Minimum & -288.02 & -80.000 & 0.1700 & 0.1300 & 6.0000 & -0.8300 & 10.540 \\
\hline Std. Dev. & 23.087 & 10.262 & 0.1229 & 0.1579 & 1.4588 & 0.3236 & 23.374 \\
\hline Skewness & -0.1042 & 14.623 & 0.0565 & 0.4365 & 0.2566 & -0.7400 & 4.1859 \\
\hline Kurtosis & 116.02 & 326.45 & 2.9352 & 1.9041 & 2.4609 & 4.3056 & 48.102 \\
\hline Jarque-Bera & 399216 & 32962. & 0.5304 & 61.357 & 17.316 & 121.72 & 65760. \\
\hline Probability & 0.0000 & 0.0000 & 0.7670 & 0.0000 & 0.0001 & 0.0000 & 0.0000 \\
\hline Sum & 1061.9 & 696.44 & 321.88 & 273.32 & 7504.0 & 423.16 & 35787 \\
\hline Sum Sq. Dev. & 399233 & 78889. & 11.325 & 18.679 & 1593.9 & 78.435 & 409243 \\
\hline Observations & 750 & 750 & 750 & 750 & 750 & 750 & 750 \\
\hline
\end{tabular}

Source: researcher summary of descriptive statistics result (2018) using E-view 8

The descriptive statistics result in Table 4.1 above displayed the mean values for each of the variables, their maximum values, minimum values, standard deviation and Jarque-Bera values which show the normality of the data. The result provides some insight into the nature of the selected quoted firms from three Sub-Sahara Africa countries that were used in the study. Firstly, it was observed that the mean and median values of unexpected core earnings expressed as a percentage of sales was $1.42 \%$ and $0.89 \%$ respectively whereas the mean and median of non-recurring item was $0.92 \%$ and $0.075 \%$. This means that on average, NREC has a high value which means that non-recurring items have been misclassified and that most of the firms within the period under study have positive non-recurring items suggesting that recurring expenses misclassification has become more pervasive and economically significant among Sub-Saharan African countries. Within the period under review, the maximum and minimum values of unexpected core earnings were 340 and -288 respectively. The large difference between the maximum unexpected core earnings and minimum unexpected core earnings revealed that the unexpected core earnings of the firms differs greatly among the firms selected and over the period under review, this shows that the firms are not homogenous. Audit committee independence revealed that on the average, about 43 percent of the audit committee members are independent while about 57 percent are non-independent. It was discovered that audit committee members have a maximum value of $75 \%$ and a minimum value of $17 \%$. The result indicates that about $37 \%$ proportion of Audit committee members in firms quoted in the Sub-Sahara Africa is financially literate/expert. In some firms, about $65 \%$ of the audit committee members are financial expert while in others only about $13 \%$ of the members are financial expert. Audit committee diligence is an indicator of the number of times the members of the audit committee meets to carry out their functions. The result indicates that members of audit committee of quoted firms in Sub-Sahara Africa on the average, held meetings for about 10 times a year, with considerable diversity across the sample ranging from 6 times to 14 times a year giving rise to minimum and maximum times respectively.

Lastly, the Jarque -Bera (JB) and its probability which test for normality or existence of outlier shows that all the variables were normally distributed at $1 \%$ level of significance except audit committee independence which shows the presence of extreme value. However, the extreme value in audit committee independence alone among other variables is not likely to distort our result; hence it can be useful in making generalization.

\subsection{CORRELATION RESULT}

In examining the relationship that exists among the variables and to check for multi-colinearity problem, the study employed the Pearson correlation matrix and the summary of the results is presented below in table 4.2.

\subsection{Pearson Correlation Result}

ACFXP

ACD

ROA

FSIZE 


\begin{tabular}{|c|c|c|c|c|c|c|c|}
\hline UNEXPCE & 1.0000 & 0.4213 & 0.0636 & 0.0693 & -0.0333 & 0.0052 & -0.0035 \\
\hline NREC & & 1.0000 & 0.0044 & -0.0617 & 0.0020 & 0.0526 & -0.0990 \\
\hline ACIND & & & 1.0000 & 0.0380 & 0.0170 & -0.0579 & 0.0656 \\
\hline ACFXP & & & & 1.0000 & -0.1771 & -0.1257 & 0.0332 \\
\hline ACD & & & & & 1.0000 & 0.1286 & -0.0232 \\
\hline ROA & & & & & & 1.0000 & 0.0283 \\
\hline FSIZE & & & & & & & 1.0000 \\
\hline
\end{tabular}

\section{Source: Researchers' summary of correlation result (2018) using E-view 8}

The result shows that unexpected core earnings was positively correlated with audit committee independence, audit committee financial expertise and return on assets but negatively correlated with audit committee diligence and firm size. We also observed a positive association between unexpected core earnings and non-recurring items which also confirms the existence of classification shifting among non-financial firms across Sub-Sahara African countries. Hence the level of unexpected core earnings can be positively and negatively influenced by those audit committee characteristics. Lastly, in checking for multi-colinearity, the study observed that no two variables were perfectly correlated. This reveals the absence of multi-colinearity problem in our model.

\subsection{REGRESSION RESULT} UNEXP-CE $=\beta_{0}+\beta_{1} N R E C_{1 t}+\beta_{2} A C I N D_{1 t}+\beta_{3} A C F X P_{1 t}+\beta_{4} A C D_{1 t}+\beta_{5} R O A_{1 t}+\beta_{6} A C D_{1 t}+\varepsilon_{1 t+\ldots . . .(3)}$

Dependent Variable: UNEXPCE

Method: Panel Least Squares

Date: 10/08/18 Time: 01:48

Sample: 20082017

Periods included: 10

Cross-sections included: 75

Total panel (balanced) observations: 750

\begin{tabular}{crccc}
\hline \hline \multicolumn{1}{c}{ Variable } & Coefficient & Std. Error & t-Statistic & Prob. \\
\hline \hline C & -7.323225 & 6.677380 & -1.096721 & 0.2731 \\
NREC & 0.966963 & 0.074818 & 12.92414 & 0.0000 \\
ACIND & -10.60725 & 6.224923 & 1.703998 & 0.0888 \\
ACFXP & -13.05445 & 4.940758 & 2.642196 & 0.0084 \\
ACD & -0.291250 & 3.534127 & -1.545283 & 0.0527 \\
ROA & -0.103730 & 2.395408 & -0.043304 & 0.9655 \\
FSIZE & 0.031523 & 0.032865 & 0.959147 & 0.3378 \\
\hline \hline R-squared & 0.691377 & Mean dependent var & 1.415973 \\
Adjusted R-squared & 0.684847 & S.D. dependent var & 23.08727 \\
S.E. of regression & 20.84453 & Akaike info criterion & 8.921349 \\
Sum squared resid & 322829.2 & Schwarz criterion & 8.964470 \\
Log likelihood & -3338.506 & Hannan-Quinn criter. & 8.937965 \\
F-statistic & 29.30768 & Durbin-Watson stat & 1.796570 \\
Prob(F-statistic) & 0.000000 & & & \\
\hline
\end{tabular}

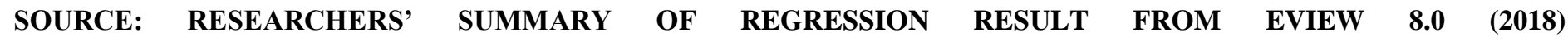
The table 4.5.5 above shows the ordinary least square regression analysis of quoted non-financial firms in three Sub-Saharan African countries namely Nigeria, Kenya and South Africa. From the result above, the study observed that the R. squared value was 0.691 $(69.1 \%)$ and R-squared adjusted value was $0.685(68.5 \%)$ approximately. The value of R- squared which is the coefficient of determination stood at $69.1 \%$ which implies that $69.1 \%$ of the systematic variations in individual dependent variables were explained in the model while about $30.9 \%$ were unexplained thereby captured by the stochastic error term. Again, the adjusted R-squared which stood at $68.5 \%$ approximately indicated that all the independent variables jointly explain about $68.5 \%$ of the system variation in unexpected core earnings/classification shifting of our sampled non-financial firms over the 10years period while about $31.5 \%$ of the total variations were unaccounted for, hence captured by the stochastic error term. This revealed that about $68.5 \%$ misclassification shifting of recurring items into non-recurring items which gave rise to unexpected core earnings/classification shifting can be attributable to the audit committee variables selected for the study while about $31.5 \%$ were unexplained. Moreover, the F-statistics value of 29.30 and its probability value of 0.000 shows that the unexpected core earnings model used for the analysis were 
statistically significant at $1 \%$ level. This confirms the appropriateness of our model used for the analysis. The Durbin Watson statistics value of 1.796 reveals the absence of autocorrelation in our model.

In addition to the above, the specific findings from each explanatory variable were provided as follows:

\section{$H_{0}$ 1: Audit committee independence has no significant effect on classification shifting of earnings management of quoted non financial firms in Sub-Sahara Africa.}

Based on t-statistics value of classification shifting and its coefficient value, the result of the analysis revealed that audit committee independence has negative coefficient value of -10.607 and P-value of 0.088 . The analysis result from the model above indicates that audit committee independence negatively influences the level of classification shifting. The result revealed that increase in audit committee independence lead to decrease in the level of classification shifting. This means that a $1 \%$ increase in the proportion of audit committee members that were independent is associated with a $-10.61 \%$ decrease in level of misclassification. By implication, this suggests that firms with more percentage of independent members in the audit committee are more likely to involve in overstating core earnings thus evidence of classification shifting. To further buttress the point, this result revealed a negative and significant effect between audit committee independence and unexpected core earnings. It further suggests that a $1 \%$ increase in the proportion of audit committee members that are independent will lead to a reduction in classification shifting practices of firms. Thus, demonstrating that classification shifting is less prevalent in firms with more independent directors in their audit committee, thus supporting the argument that having a higher proportion of independent directors in the audit committee means that they will be more likely to challenge aggressive misrepresentation of recurring items rather than monitoring less effectively. The probability value from the unexpected core earnings model reveals that the negative influence of audit committee independence on classification shifting was statistically significant at $10 \%$ level. Thus audit committee independence has negative but significant effect on classification shifting. This finding is in agreement with the prior studies of Zalata and Roberts (2016), Elbadry et al. (2015), Jouber and Fakhfakh (2010), Bradbury, Mak and Tan (2006), Xie et al. (2003) and Klein (2002) that supported the view that audit committee with more outsiders or full independence are associated with higher earnings quality and are most effective in reducing income increasing accruals and in curbing more opaque manipulation practices such as classification shifting. However, our study negates the findings of Wasukarn (2015), Adel (2015) and Vafeas (2005) that documented positive effect between audit committee independent and earnings management and the findings of Gulzar and Wang (2011), Baxter and Cotter (2009), Lin et al (2006) and Yang and Krishnan (2005) that found no evidence or significant relation between earnings management and audit committee independence. Based on this result, the study rejects the null hypothesis and accepts the alternate hypothesis; it therefore concludes that, audit committee independence has significant effect on classification shifting.

\section{$H_{0}$ 2: $\quad$ Audit committee financial expertise has no significant effect on classification shifting of earnings management of quoted non financial firms in Sub-Sahara Africa.}

The result from table 4.3 above revealed that audit committee financial expertise has coefficient value of -13.054 and P-value of 0.0084. This indicates that audit committee financial expertise has negative influence on classification shifting which was statistically significant at $1 \%$ level of significance. This means that having audit committee members with financial expertise in the audit committee can lead to a reduction in the level of classification shifting as they can oversee the internal control for financial reporting and quality of financial information thereby reducing the opportunistic behavior of the management. This demonstrates that the existence of financial experts on the audit committee is more likely to constrain managers' aggressive financial reporting decisions, at least in firms having more opportunity to classification shift. This means that having at least one financial expert in the audit committee members can enhance committee effectiveness in performing oversight functions that will lead the audit committee in indentifying and asking questions that challenge management and consequently improve financial reporting quality. Moreover, earnings management is less likely to occur for audit committee that has more experience and expertise on other boards as they are more active in monitoring since they also have reputation. While our result supports the prior results of Yang and Krishnan (2005), Xie et al. (2003), Man and Brossa (2015), Carcello et al. (2008) and Vafeas (2005), it contradicts the results of Adel Almasarwah (2015), Baxter and Cotter (2009) and Lin Radhakrishnan, and Su (2006) that found no evidence to support the existence of audit committee expertise and earnings management. Based on this result, we rejected our null hypothesis and conclude that audit committee financial expertise has negative but statistical significant effect on classification shifting of earnings management.

\section{$\mathrm{H}_{0}$ 3: Audit committee diligence has no significant effect on classification shifting of earnings management of quoted non financial firms in Sub-Sahara Africa.}

The result from table 4.3 above shows that audit committee diligence has negative coefficient value of -0.2912 , and P-value of 0.052 . The results of the analysis shows that audit committee diligence negatively influence the level of classification shifting which was statistically significant at 5\% level of significance for firms with non-recurring items suggesting that active audit committees are more likely to allocate sufficient time to discuss sophisticated accounting issues such as classification of recurring items and thus are able to constrain the classificatory manipulation. This result indicates that the more meetings held by the audit committee members in a year, the more chances they have in curbing more opaque manipulation practices such as classification shifting. As more meetings are associated with higher earnings quality. This finding was in line with the findings of Bedard et al. (2004) and Xie et al. (2003) but contradicts the findings of Gulzar and Wang (2011), Wasukarn (2015) and Vafeas (2005) that documented positive relation between frequency of audit committee meeting and earnings management and the findings of Chandrasegaram, Rahimansa, Rahman, Abdullah

www.scirj.org

(C) 2018, Scientific Research Journal

http://dx.doi.org/10.31364/SCIRJ/v6.i10.2018.P1018576 
and Nik (2013) who recorded no significant effect between frequency of meeting and earnings management. Based on the result above, we rejected our null hypothesis and accepted the alternate one and therefore conclude that audit committee diligence has significant effect on classification shifting of earnings management.

\section{0: CONCLUSION AND RECOMMENDATIONS}

This study investigated classification shifting and the overstatement of core earnings in Sub-Sahara Africa to see whether effective audit committee mitigates or collaborates misclassification of non-recurring items within income statement as firm managers have the discretionary power to allocate expenses to specific accounts subjectively and auditors cannot always accurately verify the appropriateness of their classifications. As a result of that, we placed emphasis on the role of audit committee to examine how high quality audit committees are able to constrain classification shifting of firms in Sub-Sahara Africa. We focused on classification shifting as a manipulation method due to the smaller role potentially played by the external auditor in mitigating earnings management when achieved by classification shifting. To proxy for classification shifting, we examined the misclassification of core expenses into non-recurring items within the income statement as an earnings management tool following McVay (2006) and Athanasakou et al. (2009) model. The results revealed that classification shifting is less prevalent in firms whose audit committee is characterized by more meetings, more financial expert members and more directors that were independent of the management as this leads to lower levels of recurring items misclassification. This supports the view that audit committee members that are independent and with financial expertise are most effective in mitigating earnings management.

However, based on the following findings, we suggest that users of financial statements should take account of firms' audit committee characteristics when evaluating firms' core earnings. In addition to this, we make the following recommendations:

I. Non-financial firms in Sub-Sahara Africa should ensure that their audit committees are constituted by more independent persons with high level of integrity that can match words with action.

II. Proportion of audit committee members with financial expertise and knowledge should be increased among non-financial firms in the Sub-Sahara Africa.

III. Audit committee members should try as much as possible to have meetings on regular basis so that important issues with respect to disclosure requirement will be dealt with as soon as they arise.

\section{REFERENCES}

Abbott, L.J., Parker, S. and Peters, G.F. (2004). Audit Committee Characteristics and Restatements. Auditing: A Journal of Practice \& Theory, 23(1) 69-87.

Abbott, L.J., Parker, S. Peter, G.F and Raghunandan, K. (2003). The association between audit committee characteristics and audit fee. Journal of auditing practice and theory 22(2)17-32.

Agrawal, A. and Chadha, S. (2005). Corporate Governance and Accounting Scandals. Journal of Law and Economics, 43(2) 371-406.

Afify, H. (2009). Determinants of Audit Report lag: Does implementing corporate governance have any impact. Empirical Evidence from Egypt. Journal of Applied Accounting Research, 10(1) 56-86.

Athanasakou, V. E., Strong, N. C. and Walker, M. (2009). Earnings Management or Forecast Guidance to Meet Analyst Expectations? Accounting and Business Research 49 (1): 3-35

Barua, A., Lin, S.and Sbaraglia, A. M. (2010). Earnings Management Using Discontinued Operations. The Accounting Review 85 (5): 1485-1509.

Bedard, J., Chtourou, S.M. and Courteau, L. (2004). The Effect of Audit Committee Expertise, Independence, and Activity on Aggressive Earnings Management. Auditing: A Journal of Practice and Theory, 23(2) 15-35.

Benkel, M, Mather, P \& Ramsay, A (2006). The Association between Corporate Governance and Earnings Management: The Role of Independent Directors', Corporate Ownership \& Control, 3(4), 65-75.

Baxter, P. and Cotter, J. (2009). Audit committees and earnings quality. Accounting and fianace, 49(1), 267-290 
Bhattacharya, N., Black, E. L., Christensen, T. E., and Mergenthaler, R. (2007). Who trades on proforma earnings information? The Accounting Review, 82,581-619.

Bradshaw, M., and R. Sloan. (2002). GAAP versus the street: an empirical assessment of two alternative definitions of earnings. Journal of Accounting Research,40 (1): 41-65.

Bradbury, M. E., Mak, Y. T. and Tan, S. M. (2006). Board characteristics, audit committee characteristics and abnormal accruals. Pacific Accounting review, 18(2), 47-68

Cameron, R. and Gallery, N. (2012). Were regulatory changes in reporting abnormal items justified? Journal of Acoounting \& Organisational change 8(2): 160-185

Carcello, J.V., Hollingsworth, C.W., Klein, A. and Neal, T.L. (2006). Audit Committee Financial Expertise, Competing Corporate Governance Mechanisms, and Earnings Management.

Carter, D.A., Simkins, B.J. and Simpson, W.G. (2003). Corporate Governance, Board Diversity, and Firm Value. Financial Review, 38(1) 33-53.

Chandrasegaram, R., Rahimansa, M. R., Rahman, S. K. A., Abdullah, S., Nik Mat, N. (2013). Impact of audit committee characteristics on earnings management in Malaysia Public listed companies. International Journal of finance and Accounting, 2(2), 114-119

Choi, J.H., Jeon, K. A. and Park, J. I. (2004). The role of audit committees in decreasing earnings management: Korean evidence. International Journal of Accounting and Performance Evaluation, HongKong.

Davidson, R, Goodwin-Stewart, J and Kent, P (2005). Internal governance structures and earnings management. Accounting \& Finance, 45(2), 241-267.

Dhaliwal, D., Naiker, V. and Navissi (2010). The association between accrual quality and the characteristics of accounting experts and mix of expertise on audit committees. Contemporary Accounting Research, 27(3), $787-827$

Dechow, P. M. and Dichev, I. D. (2002). The quality of accruals and earnings: The role of accrual estimation errors. The Accounting review, 77(1), 35-59

Dey, A. (2005). Corporate governance and financial reporting credibility', Ph.D.thesis, Northwestern University.

Dezoort, F.T and Salterio, S.E(2001). The effects of corporate governance experience and financial reporting and audit knowledge on audit committee member judgments. A journal of auditing practice and theory 20(2)31-47

Emeh, Y. and Appah, E. (2013), Audit committee and timeliness of financial reports. Economics and sustainable development 4(20), 14-25.

Fan, Y., Barua, A., Cready, W.M. and Thomas, W. (2010). Managing earnings using classification shifting. Evidence from quarterly special items. The Accounting Review, 85, 1303-1323

Felo, A.J., S. Krishnamurthy and S. A. Solieri (2003). Audit Committee Characteristics and the Perceived Quality of Financial Reporting: An Empirical Analysis”. Working paper, Penn State Great Valley.

Frankel, R., McVay, S., and Soliman, M. (2011). Non-GAAP earnings and board independence. Review of Accounting Studies, 16, 719-744

Habbash M. (2010). The effectiveness of corporate governance and external audit on constraining earning management practices in the UK. PhD. Thesis, Durham University

Hashim, H. A and Abdul Rahman, M.S (2011). Multiple Board Appointment; Are directors Effective?. International Journal of business and social science, 2(17): 137-143

wwW.scirj.org

(C) 2018, Scientific Research Journal

http://dx.doi.org/10.31364/SCIRJ/v6.i10.2018.P1018576 
Haw, I. M., Ho, S. S., and Li, A. Y. (2011). Corporate governance and earnings management by classification shifting. Contemporary Accounting Research, 28(2), 517-553.

Hossain, M., Mitra, S., Rezaee, Z., and Sarath, B. (2011). Corporate governance and earnings management in the pre-and post-Sarbanes-Oxley Act regimes evidence from implicated option backdating firms. Journal of Accounting, Auditing \& finance, 26,279-315.

Klein, A. (2002). Audit Committee, Board of Director Characteristics, and Earnings Management. Journal of Accounting and Economics, 33(3) 375-400.

Lin, J.W. and Hwang, M.I.(2010). Audit quality, corporate governance and earnings management: A meta-analysis. International Journal of Auditing, 14, 57-77.

Li, J. Pike, R., and Haniffa, R. (2008). Intellectual capital disclosure and corporate governance structure in U.K. Accounting and Business research 38(2)136-159.

Lin, S., S. Radhakrishnan, and L. Su. (2006). Earnings management and guidance for meeting or beating analysts' earnings forecasts. Working paper, California State University, Fresno, The University of Texas at Dallas, and Hong Kong Polytechnic University

McVay, S.E (2006). Earnings management using classification shifting: An examination of core earnings and special items. Accounting Review, 81(3), 501.

Mohamad, M.N, Shafie R. and Wan-Hussin, W.N (2010) Corporate governance and audit report lag in Malaysia, Asian Academy of management. Journal of accounting and finance 6(2):57-84

Park, W.Y. and Shin, H.H. (2003). Board composition and earnings management in Canada. Journal of Corporate Finance, 185, 1-27.

Peasnell, K.V., Pope, P.F. and Young, S. (2005). Board Monitoring and Earnings Management: Do Outside Directors Influence Abnormal Accruals? Journal of Business Finance and fAccounting, 32(7) \& (8), 1311-1346

Person, (2009). Auditing committee characteristics and earlier voluntary ethics disclosure among fraud and no- fraud firms. International journal of disclosure and governance 6(4), 284-297.

Peter, B. and Cotter, J. (2009). Audit committees and earnings quality. Accounting and finance, 49(2), 267-290

Rahman, R. A. and Ali, F.H. M. (2006). Board, audit committee, culture and earnings management: Malaysian evidence. Managerial Auditing Journal, 21(7) 783-804

Scott, (2012). Financial Accounting Theory. (6 ${ }^{\text {th }}$ Ed). Pearson Prentice Hall, Toronto

Sharma, V., Naiker, V., and Lee, B. (2009). Determinants of audit committee meeting frequency: Evidence from a voluntary governance system. Accouting Horizons, 23, 245-263.

Sharinah, P., Salleh, M.F. and Azlina, A. (2014). Audit committee and Timeliness of financial reporting. Malaysian Public listed companies. Middle-East Journal of scientific Research 22(2): 162-175.

Sri, M. and Sylvia, F., (2016). The influence of Audit Committee composition, Resources Reporting Quality. International business management. Medwell Journals. 10(9); 1756-1767.

Turner, L. and Vann, E. (2010). Audit Committee Independence and Earnings Management: How Independent are Independent Directors? Journal of Forensic \& Investigative Accounting, 2 (3), 1-41

Vafeas, N. (2005). Audit committees, boards and the quality of reported earnings. Contemporary

WWW.scirj.org

(C) 2018, Scientific Research Journal

http://dx.doi.org/10.31364/SCIRJ/v6.i10.2018.P1018576 
Accounting research 22(4), 1093-1122

Wasukarn, N. (2015). Impact of board effectiveness and shareholders structure on earnings management in Thailand. Review of integrative business and economics research 4(2), 342-354

Watts, R.L., Zimmerman, J.L., (1986). Positive Accounting Theory. Contemporary Topics in Englewood Cliffs, NJ, USA.

Wu, E. (2016). Classification shifting as an earnings management tool among European firms. Master's Thesis. Erasmus Universiteit Rotterdam .

Xie, B., Davidson III, W.N. and DaDalt, P.J. (2003). Earnings Management and Corporate Governance:The Roles of the Board and the Audit Committee. Journal of Corporate Finance, 9 295-316.

Yang, J. S., and Krishnan, J., (2005). Audit committees and quarterly earnings management. International Journal of Auditing, 9, 201-209.

Zalata, A., and C. Roberts. (2016). Internal Corporate Governance and Classification Shifting Practices: An Analysis of U.K. Corporate Behavior. Journal of Accounting, Auditing \& Finance 51-78.

\section{APPENDICES}

\section{DESCRIPTIVE STATISTICS RESULT}

\begin{tabular}{|c|c|c|c|c|c|c|c|}
\hline & UNEXPCE & NREC & ACIND & ACFXP & ACD & ROA & FSIZE \\
\hline Mean & 1.415973 & 0.928587 & 0.429173 & 0.364427 & 10.00533 & 0.564213 & 47.71620 \\
\hline Median & 0.890000 & 0.075000 & 0.500000 & 0.330000 & 10.00000 & 0.610000 & 46.70000 \\
\hline Maximum & 340.5500 & 226.9700 & 0.750000 & 0.650000 & 14.00000 & 1.580000 & 317.1900 \\
\hline Minimum & -288.0200 & -80.00000 & 0.170000 & 0.130000 & 6.000000 & -0.830000 & 10.54000 \\
\hline Std. Dev. & 23.08727 & 10.26285 & 0.122968 & 0.157923 & 1.458815 & 0.323605 & 23.37491 \\
\hline Skewness & -0.104256 & 14.62363 & 0.056518 & 0.436599 & 0.256693 & -0.740041 & 4.185997 \\
\hline Kurtosis & 116.0260 & 326.4564 & 2.935212 & 1.904113 & 2.460969 & 4.305631 & 48.10254 \\
\hline Jarque-Bera & 399216.0 & 3296232. & 0.530461 & 61.35759 & 17.31625 & 121.7286 & 65760.30 \\
\hline Probability & 0.000000 & 0.000000 & 0.767029 & 0.000000 & 0.000174 & 0.000000 & 0.000000 \\
\hline Sum & 1061.980 & 696.4400 & 321.8800 & 273.3200 & 7504.000 & 423.1600 & 35787.15 \\
\hline Sum Sq. Dev. & 399233.4 & 78889.24 & 11.32569 & 18.67970 & 1593.979 & 78.43549 & 409243.6 \\
\hline Observations & 750 & 750 & 750 & 750 & 750 & 750 & 750 \\
\hline \multicolumn{8}{|c|}{ CORRELATION RESULT } \\
\hline & UNEXPCE & NREC & ACIND & ACFXP & ACD & ROA & FSIZE \\
\hline UNEXPCE & 1.000000 & 0.421301 & 0.063681 & 0.069395 & -0.033307 & 0.005214 & -0.003579 \\
\hline NREC & 0.421301 & 1.000000 & 0.004478 & -0.061771 & 0.002048 & 0.052652 & -0.099003 \\
\hline ACIND & 0.063681 & 0.004478 & 1.000000 & 0.038023 & 0.017068 & -0.057903 & 0.065623 \\
\hline ACFXP & 0.069395 & -0.061771 & 0.038023 & 1.000000 & -0.177148 & -0.125764 & 0.033219 \\
\hline $\mathrm{ACD}$ & -0.033307 & 0.002048 & 0.017068 & -0.177148 & 1.000000 & 0.128605 & -0.023262 \\
\hline ROA & 0.005214 & 0.052652 & -0.057903 & -0.125764 & 0.128605 & 1.000000 & 0.028338 \\
\hline FSIZE & -0.003579 & -0.099003 & 0.065623 & 0.033219 & -0.023262 & 0.028338 & 1.000000 \\
\hline
\end{tabular}

REGRESSION RESULT

Dependent Variable: UNEXPCE

Method: Panel Least Squares

Date: 10/08/18 Time: 01:48

Sample: 20082017

Periods included: 10

Cross-sections included: 75

Total panel (balanced) observations: 750 


\begin{tabular}{crcrc}
\hline \hline Variable & Coefficient & Std. Error & t-Statistic & Prob. \\
\hline \hline C & -7.323225 & 6.677380 & -1.096721 & 0.2731 \\
NREC & 0.966963 & 0.074818 & 12.92414 & 0.0000 \\
ACIND & -10.60725 & 6.224923 & 1.703998 & 0.0888 \\
ACFXP & -13.05445 & 4.940758 & 2.642196 & 0.0084 \\
ACD & -0.291250 & 3.534127 & -1.545283 & 0.0527 \\
ROA & -0.103730 & 2.395408 & -0.043304 & 0.9655 \\
FSIZE & 0.031523 & 0.032865 & 0.959147 & 0.3378 \\
\hline \hline R-squared & 0.691377 & Mean dependent var & 1.415973 \\
Adjusted R-squared & 0.684847 & S.D. dependent var & 23.08727 \\
S.E. of regression & 20.84453 & Akaike info criterion & 8.921349 \\
Sum squared resid & 322829.2 & Schwarz criterion & 8.964470 \\
Log likelihood & -3338.506 & Hannan-Quinn criter. & 8.937965 \\
F-statistic & 29.30768 & Durbin-Watson stat & 1.796570 \\
Prob(F-statistic) & 0.000000 & & \\
\hline \hline
\end{tabular}

\section{REGRESSION RESULT (INTERACTION MODEL)}

Dependent Variable: UNEXPCE

Method: Panel Least Squares

Date: 10/08/18 Time: 02:00

Sample: 20082017

Periods included: 10

Cross-sections included: 75

Total panel (balanced) observations: 750

\begin{tabular}{lrlrl}
\hline \hline \multicolumn{1}{c}{ Variable } & Coefficient & Std. Error & t-Statistic & Prob. \\
\hline \hline C & -4.585732 & 2.811568 & -1.631023 & 0.1033 \\
NREC*ACIND & 1.959876 & 0.148258 & 13.21935 & 0.0000 \\
ACFXP*ACD & -1.022336 & 0.477026 & 2.143145 & 0.0324 \\
$\quad$ ROA & -0.399018 & 2.358699 & -0.169169 & 0.8657 \\
$\quad$ FSIZE & 0.036649 & 0.032691 & 1.121055 & 0.2626 \\
\hline \hline R-squared & 0.702167 & Mean dependent var & 1.415973 \\
Adjusted R-squared & 0.687830 & S.D. dependent var & 23.08727 \\
S.E. of regression & 20.80635 & Akaike info criterion & 8.915038 \\
Sum squared resid & 322513.7 & Schwarz criterion & 8.945839 \\
Log likelihood & -3338.139 & Hannan-Quinn criter. & 8.926906 \\
F-statistic & 44.30520 & Durbin-Watson stat & 1.793963 \\
Prob(F-statistic) & 0.000000 & & \\
\hline \hline
\end{tabular}

